Отримано: 20 травня 2019 року

Прорецензовано: 22 травня 2019 року

Прийнято до друку: 23 травня 2019 року

e-mail: sevschool@yandex.ua

DOI: $10.25264 / 2519-2558-2019-6(74)-196-199$
Nataliya Samoylenko. Communication effectively in international contexts: challenges and good practises. Наукові записки Начіонального університету «Острозька академія»: серія «Філологія». Острог: Вид-во НаУОА, 2019. Вип. 6(74), червень. С. 196-199.

Nataliya Samoylenko,

Doctor (Pedagogy), associate professor, Sevastopol State University

\title{
COMMUNICATION EFFECTIVELY IN INTERNATIONAL CONTEXTS: CHALLENGES AND GOOD PRACTISES
}

English Medium Instruction (EMI) courses are becoming familiar in universities around the globe. Increasing numbers of academics and teachers working in universities around the world are being asked to teach in English and work with international students. Over the last decade research on English as a lingua franca, Global Englishes demonstrated that English is not a barrier but a tool. However many recent studies focus on investigating different contexts of EMI around the world, language, structures to use to present our ideas clearly. Despite the importance of research on English as a lingua franca, Global Englishes, English as a Medium of Instruction (EMI) has not yet become a subject of research. This paper attempts to give an introduction to English as a Medium of Instruction (EMI) and how to get prepared for the global classroom. It is also shown how to focus on some key aspects of the EMI, which help us to change our practice, the way we teach and to prepare to adjust our pedagogical approach somewhat and adapt our style and methods in order to take account of the needs of our intercultural communication. As a result this study raises a broader question: How to communicate effectively in international contexts? This issue will be discussed in connection with the pedagogical implications arising from the findings and observations of the study.

Key words: English Medium Instruction (EMI), English as a lingua franca, Global Englishes, intercultural communication, international contexts.

\section{Самойленко Наталія Борисівна,}

доктор педагогічних наук, дочент, Севастопольський державний університет

\section{ЕФЕКТИВНА КОМУНІКАЦІЯ В МІЖНАРОДНИХ КОНТЕКСТАХ: ВИКЛИКИ ТА ПРАКТИКИ}

У статті досліджується проблема ефективної комунікації в міжнародному контексті. В університетах у всьому світі з'являються курси з English Medium Instruction (EMI). Відображено сутність поняття English Medium Instruction (EMI), aнглійська мова, що функиіонує як lingua franca, Global Englishes. Розкриваються ключові acneкти English Medium Instruction (EMI), які допомагають змінити практику й методи викладання, врегулювати педагогічний підхід, стиль $і$ методи підготовки студентів до міжкультурної комунікації і взаємодії. Автором продемонстровано приклади матеріалів для студентів з оволодіння основ письмової англомовної комунікаиї̈ в науково-освітній галузі для проведення наукових досліджень.

Ключові слова: English Medium Instruction (EMI), lingua franca, Global Englishes, міжкультурна комунікація, міжнародний контекст.

Introduction. It is now generally accepted that English Medium Instruction (EMI) courses are becoming familiar in universities around the globe. Increasing numbers of academics and teachers working in universities around the world are being asked to teach in English and work with the international students.

Problem statement. In recent years researchers have become increasingly interested in: How to communicate effectively in international contexts? What is EMI? Many recent studies focus on investigating different contexts of EMI around the world, language, structures to use to present our ideas clearly, how important it is to be accurate with our language. Over the last decade research on English as a lingua franca, Global Englishes demonstrated that English is not a barrier but a tool. And there are other tools and resources in our repertoire of skills that we can make use for communication. Despite the importance of research on English as a lingua franca, Global Englishes little attention has been paid to English as a Medium of Instruction (EMI) [3; 9; 10].

Research questions. As universities work the researches and tutors teach their courses in English. But working in Higher Education they do not have training in English language or intercultural skills.

Methodology. Our research aims to give an introduction to English as a Medium of Instruction (EMI) and get prepared for the global classroom. We will focus on some key aspects of the EMI, which help us to change our practice, the way we teach, to prepare to adjust our pedagogical approach, to adapt our style and methods in order to take account of the needs of our intercultural communication.

Findings. Since joining the University in 2005 I have taught on most programmes and modules that the English Language Section has offered. This also includes directing Masters' Courses for many years, preparing for TKT exams and organizing CPD activities [4]. Our commitment now is to develop our English Medium Instruction options for academics within our own university. We are interested in the work of the British Association of Lecturers in English for Academic Purposes on the subject of EMI (https:// www.baleap.org/).

According to Dr. Nicola Galloway, co-author of a recent report into English as a medium of instruction, the growing trend is to teach university courses in English. The practical reasons of English as a medium of instruction growing are:

1) most academic research is published in English (about 94 per cent of research in international, high-impact publications is in English);

2) the universities, where students tend to be highly proficient in English, have often switched to English, especially for courses in science, technology, engineering and mathematics (STEM);

3) many governments believe that EMI programmes will improve students' English proficiency, make them more attractive in the global job market; 
because English is the language of research, the graduates' could increase the amount of English-language research they get published in international journals, raising the university's position in rankings ().

It is now generally accepted English is used in teaching and learning at universities around the world. The researchers consider importance of English use in international higher education and a variety of approaches English is used in education. They discuss the difference between CLIL (Content and Language Integrated Learning) and EMI, and reflect on the language needs of students working and studying in international settings.

Thanks to the research of scholars such as Anna Mauranen from the University of Helsinki and Jennifer Jenkins from the University of Southampton who have promoted research into English as it is actually used now in the world today by its millions of users only a small percentage of whom are native speakers of the language, English is considered the world's language. It's lingua franca [7].

For academics, teachers and students all over the world, decisions are made for one reason or another to deliver course content subject matter through the medium of English. There is no single standard model of EMI, but rather a vast number of possible variations. For example, a university may choose to operate totally in English with all its support services, administration, library resources, and so on able to operate in English, and thus, in an almost totally English-dominant environment.

One of the characteristic features of using English is - teaching and learning is happening at a distance, thanks to technology, with varying degrees of separation between teachers and students. An academic may be in one location and the students in several others, or lectures are recorded to be listened to later, or MOOCs or other online courses are created for students to enroll on. [10].

The authors of the online course, devoted to EMI highlight the role of English for effective communication. When we think about successful communication, we think of the actual words we use when we speak English in a given situation. These are the building blocks in any language. But our objective goes beyond just words. The clue is in the name - English Medium Instruction. We are not teachers of English, but teachers in English. This is the difference between EMI and CLIL which is another term you may have heard of. CLIL stands for Content and Language Integrated Learning. And CLIL has two functions - to teach both content and a language at the same time [10].

In some universities, there is the distinction between EMI and CLIL. But the researchers of this course consider EMI as the teaching of academic content through English, not the teaching of English. Language grows and develops through use and practice; the students may acquire more proficiency and confidence in their English language skills through participating in EMI classes. But primary aim remains to teach the contents of discipline.

The scholars put forward the analysis of English, which needs to be perfect knowledge. The researches consider English as not a barrier but as a tool. To help us communicate we can use other tools and resources [9].

We compared opinions of the researchers. The native speakers are positive towards EMI, because it opens doors on a global level for them; allows to look into teaching in other countries, and to publish, to go to conferences. But, as a global Englishes researcher, they think that it is so important to be critically aware of the local contexts [6].

EMI has been extensively studied in recent years by EMI Oxford (The Centre for Research and Development in English Medium Instruction), a center based in the University of Oxford's Department of Education. The researchers attempted to provide an initial picture of the rapidly growing global phenomenon of English medium instruction (EMI). Their definition of EMI is: "The use of the English language to teach academic subjects in countries or jurisdictions where the first language (L1) of the majority of the population is not English" [9, p. 6].

Although considerable amount of research has been devoted to the English language for teaching academic subjects few attempts have been made to investigate EMI. The last investigations have focused on EMI definitions and reasons of its appearance (table 1).

EMI definitions, functions and reasons of its appearance

Table 1

\begin{tabular}{|c|l|l|l|}
\hline № & \multicolumn{1}{|c|}{ EMI in education } & \multicolumn{1}{c|}{ Functions } & \multicolumn{1}{c|}{ Reasons } \\
\hline & $\begin{array}{l}\text { EMI is practiced very differ- } \\
\text { ently around the world with } \\
\text { other languages present, with } \\
\text { different forms of assessment } \\
\text { and support, with different } \\
\text { first language groups present }\end{array}$ & $\begin{array}{l}\text { - Helps to create a dialogical space for glob- } \\
\text { al citizens to connect and make the world a } \\
\text { more peaceful and interconnected place. } \\
\text { - Presents an opportunity for people from } \\
\text { different backgrounds to engage, rather than } \\
\text { a challenge to other languages. }\end{array}$ & $\begin{array}{l}\text { - To adapt people's language and express them- } \\
\text { selves in a way that is right for them; } \\
\text { - English is inclusive and multicultural to be the } \\
\text { lingua franca of higher education. }\end{array}$ \\
\hline $\begin{array}{l}\text { English in EMI is a way of } \\
\text { communicating ideas }\end{array}$ & $\begin{array}{l}\text { - Does not necessarily have a fixed or stan- } \\
\text { dard form. } \\
\text { - English forms can be very varied in EMI } \\
\text { settings, within very different cultural } \\
\text { spaces. }\end{array}$ & $\begin{array}{l}\text { Teaching through English can enhance language } \\
\text { skills for staff and students. } \\
\text { Using English in academic life enables new connec- } \\
\text { tions to form and opens up opportunities to publish } \\
\text { students' work in a range of journals or books. }\end{array}$ \\
\hline
\end{tabular}

Language and intercultural communication skills are considered to be basic skills in our globalizing world [1; 12]. Professor of Global Englishes at the University of Southampton Jennifer Jenkins coincides that today Global Englishes is changing fast [5]. Scholars from different countries in their researches highlight the role of Global Englishes and intercultural communication in English Language Teaching. Now, English as a Lingua Franca is different because English as a Lingua Franca is not about a variety of English. It's about English used as a contact language, or a language of intercultural communication.

The other major piece of research was the English as a Lingua Franca in Academia Corpus (ELFA), which was led by Professor Anna Mauranen at the University of Helsinki. She focused on Academic ELF rather than other kinds of ELF context and use, when she started researching ELF [7].

Academics across all disciplines are observing how researchers at various levels of experience write about their published research. Everyone doing research reads and critically discusses the previously published research on their topic. Researchers know what to do but actually, many research students face the problem in essential questions. Investigating the research writing experience, doing research writing for the first time, we need for explicit discussion and instruction in this area [6-8]. 
Nowdays, the concept English for Academic Purposes (EAP) has been the major driver for the changes in the English as a Foreign Language (EFL) programme at Sevastopol State University. By the end of Master course, students will be able to: read written materials, evaluate them critically for further use in their teaching and research work; make presentations using appropriate logical structure, highlighting significant points; produce different types of academic writing, including articles, research reports, summaries, reviews and reports on professional issues, research papers; reference resources [1].

Therefore we need to learn the kind of English which is used in academic contexts, academic textbooks and articles, lectures and seminars; what vocabulary relating to being a student at a university or college present [3].

That is why in an academic institution English has become the medium of instruction. The students attend or give lectures and presentations in English, participate in international conferences, write up a dissertation in English [3].

This paper focuses on research academic English study. Studying the academic English we present the kind of vocabulary that is used in academic speech and writing, for discussing ideas and research and for talking and writing about academic work that you need to be fully familiar with in order to feel comfortable in an academic environment.

The researcher considers "academic English tends to be a truly international language we focus on vocabulary that will be essential for you regardless of where you are studying now or may study in the future" [3, p.10].

We agree with the author that we are teaching English as a means of international communication, the scholars are daily required to study English, in order to communicate in this language when discussing their professional subjects. Nowdays the purpose is to find ways and means of making human linguistic communication more effective, a form of English to speak and write on professional subject. The researcher defines a corpus as a representative sample of language, compiled for the purpose of linguistic analysis. It provides accessible data for the use of different researchers. Its range and size are variable.

There are many differences between formal, neutral and informal vocabulary in English. Here we list a number of words and expressions that are frequent in academic contexts, prepared by the students. The students use such resources, the cited books: A University Grammar of English by Randolph Quirk, Sidney; Academic Vocabulary in Use by Michael McCarthy, Felicity O'Dell (Cambridge University press); Cambridge Dictionary http://dictionary.cambridge.org; Greenbaum, Geoffrey Leech, Jan Svartvik (Longman); Longman Dictionary of Contemporary English (Longman) http://www.ldoceonline.com; Macmillan Collocations Dictionary (Macmillan); Macmillan English Grammar in Context by Michael Vince (Macmillan); Merriam Webster https://www.merriam-webster.com; Practical English Usage by Michael Swan (Oxford); T. V. Yakhontova «English academic writing for students and researchers»; The Oxford Dictionary of Literary Terms: https://www.oxforddictionaries.com [4].

For their own glossary or term list by their Master's theses the students choose neutral vocabulary, appropriate for written and spoken contexts.

The students use site "Welcome to English Vocabulary Exercises" (). The Academic Word List (AWL) is a list of words which appear with high frequency in English-language academic texts. The list was compiled by Averil Coxhead at the Victoria University of Wellington, New Zealand. Averil Coxhead is a lecturer in English for Academic Purposes at Massey University, Palmerston North, New Zealand. She compiled the AWL in 2000. (index. Shtml)._The list contains 570 word families and is divided into 10 sublists. The AWL is organized into Word Families.

Teaching academic writing at universities is a new trend. The undergraduate students need to have good critical writing skills for taking part in different international programs and contests, publish their research papers in international journals, apply for grants and internships, study at colleges and universities abroad, work in international companies and institutions. We conduct research academic writing (RAW) course for Master's programs. Undergraduate students' writing includes term and Master's course papers, theses [2].

We use materials from international writing centers, journals, and our students' papers. We made up activities for the course and borrowed some of them from online sources, expanded, changed, and adapted to philology majors. For selecting a good research question we design activity for analyzing if the topic is researchable. Studying the abstract writing and abstract structure, the students highlight and label the parts of the abstracts. When the students submit their research papers to their native language journal, they are supposed to write an abstract in their native language. Therefore they should follow the same structure and criteria [1;4]. We design some activities: the students are united in groups and present their results and decide which abstracts to choose or reject for publishing. They discuss their selection criteria, taking into consideration: content, clarity, language, the length, the quality of the abstract.

Most students from their baccalaureate programs know how to plan research, collect and analyze data, interpret results, and how to write a research paper. But the research academic writing course is intended for undergraduate students involved in writing Master's theses to be presented in native language by the end of their study and in English language by the end of the course.

Conclusion. We conclude that EMI appears to be a phenomenon. In general, this investigation shows that we need 'global' understanding of the aims and purposes of EMI. Further research is needed to verify a research of EMI and the effects of EMI on the learning of academic subjects and on the acquisition of English proficiency; to design pedagogical guidelines which might lead to effective EMI teaching and learning; creating EMI content in initial teacher education (teacher preparation) programmes and continuing professional development (in-service) courses.

\section{References:}

1. Кузьменкова Ю. Б. Аcademic project presentations: Student's Workbook: Презентация научных проектов на английском языке: Учебное пособие для студентов старших курсов и аспирантов. 3-е издание. Москва: Издательство Московского университета. 2011. $132 \mathrm{c}$.

2. Луганская Е. В., Гатто М. А. Understanding the Research Procedure: Writing Activities for Business Students : учеб. пособие. Иркутск : Изд-во ИГУ, 2017.93 с.

3. Ляпунова Е. Э. От лингвистики к лингводидактике: Выпуск I: What is the core EAP we use in the Humanities? Справочно-теоретическая трактовка базовых характеристик английского языка для общеакадемических целей. Москва: МАКС Пресс, 2013. 76 с.

4. Самойленко Н. Б. Developing Academic writing in intercultural university settings: key features, efficiency and challenges. Hayкові записки Національного університету «Острозька академія». Серія «Філологічна» : збірник наукових праць / укладачі : І. В. Ковальчук, О. Ю. Костюк, Л. М. Коцюк. Острог : Видавництво Національного університету «Острозька академія», 2016. Вип. 60. 330 c. C. $7-10$. 
5. Самойленко Н. Б. Preparing students to meet the demand for 21 century skills: opportunities, challenges, Expectations. Bicник Національного авіаційного університету. Серія: Педагогіка. Психологія: зб. наук. пр. Київ: Національний авіаційний університет, 2018. Вип. 1(12). 144 с. С. 93-99.

6. Самойленко Н. Б. Using English as a lingua franca: teaching and learning languages. Наукові досягнення, відкриття та шляхи розвитку педагогічної науки: матеріали Всеукраїнської науково-практичної конференції, м. Запоріжжя, 25-26 травня 2018 р. Запоріжжя: Класичний приватний університет, 2018. 116 с. С. 68-70.

7. Changing English: Global and Local Perspectives / Filppula, M. (ed.), Klemola, J. (ed.), Mauranen, A. K. (ed.) \& Vetchinnikova, S. (ed.) 2017 Berlin, Boston: De Gruyter Mouton. 347 p. (Topics in English Linguistics [TiEL]; no. 92.

8. Crystal D. English as a global language Second edition. Cambridge: CUP, 2003, 2nd edition. 212 pp.

9. Dearden J. English as a Medium of Instruction: a growing global phenomenon, 2015. 40 p. URL: https://www. britishcouncil. org/ sites/default/files/e484_emi__cover_option_3_final_web.pdf (accessed 27.02.2019).

10. English as a Medium of Instruction for ${ }^{-}$Academics. URL: https://www.futurelearn.com/courses/emi-academics// (accessed 27.02.2019).

11. Englishes. A resource book for students / J. Jenkins. Abingdon, GB: Routledge, 3rd edition, 2015. 288 p.

12. Jenkins J. Mobility and English language policies and practices in higher education in The Routledge Handbook of Migration and Language / ed. J. Jenkins: 1st, Chapter: 28, Publisher: Routledge, Editor: Suresh Canagarajah, 2017. PP. 502-518.

13. Mauranen A. English as a global Lingua Franca: changing language in changing global academia. In Murata, K. (ed.) Exploring ELF in Japanese Academic and Business Contexts. Amsterdam: John Benjamins, 2015. P. $29-46$.

14. The University of Southampton. URL: https://www.southampton. ac.uk/ml/ about/ staff/ wmlb.page. / (accessed 27.02.2019).

15. English as a Medium of Instruction for Academics. URL: https://www.futurelearn.com/courses/emi-academics/ (accessed 27.02.2019). 